\title{
3D models related to the publication: Patterns of bilateral asymmetry and allometry in Late Devonian Polygnathus conodonts
}

\author{
Catherine Girard ${ }^{1 *}$, Anne-Lise Charruault ${ }^{1}$, Ronan Ledevin²,3, Sabrina Renaud ${ }^{2}$ \\ ${ }^{1}$ Institut des Sciences de l'Evolution de Montpellier (ISEM), Univ Montpellier, CNRS, EPHE, IRD, Montpellier, France \\ ${ }^{2}$ Laboratoire de Biométrie et Biologie Evolutive, UMR 5558 CNRS, Université Claude Bernard Lyon 1, Université de Lyon, 69100 Villeurbanne, France \\ ${ }^{3}$ Current address: UMR5199 PACEA, Université de Bordeaux, Allée Geoffroy Saint Hilaire (Bat. B8), 33615 PESSAC, France \\ ${ }^{*}$ Corresponding author: catherine.girard@umontpellier.fr
}

\begin{abstract}
This contribution contains the 3D models of the set of Famennian conodont elements belonging to the species Polygnathus glaber and Polygnathus communis analyzed in the following publication: Renaud et al. 2021: Patterns of bilateral asymmetry and allometry in Late Devonian Polygnathus. Palaeontology, https://doi.org/10.1111/pala.12513.
\end{abstract}

Keywords: Conodonts, Late Devonian, Polygnathus communis, Polygnathus glaber

Submitted:2020-08-11, published online:2021-03-03. https://doi.org/10.18563/journal.m3.126

\begin{tabular}{|c|c|c|}
\hline nv. $\mathrm{Nr}$ & Taxon & Description \\
\hline UM BUS 001 & Polygnathus glaber & right $\mathrm{P} 1$ element \\
\hline UM BUS 002 & Polygnathus glaber & element \\
\hline UM BUS 003 & Polygnathus glaber & ght P1 element \\
\hline UM BUS 004 & Polygnathus glaber & left P1 element \\
\hline UM BUS 005 & Polygnathus glaber & left P1 element \\
\hline UM BUS 006 & Polygnathus glaber & right $\mathrm{P} 1$ element \\
\hline UM BUS 007 & Polygnathus glaber & right $\mathrm{P}$ \\
\hline UM BUS 008 & Polygnathus glaber & left P1 element \\
\hline UM BUS 009 & Polygnathus glaber & left P1 element \\
\hline UM BUS 010 & Polygnathus glaber & right $\mathrm{P}$ \\
\hline UM BUS 011 & Polygnathus glaber & right $\mathrm{F}$ \\
\hline UM BUS 012 & Polygnathus glaber & right $\mathrm{P}$ \\
\hline UM BUS 013 & Polygnathus glaber & left $\mathrm{P}$ \\
\hline UM BUS 014 & Polygnathus glaber & left P1 element \\
\hline UM BUS 015 & Polygnathus glaber & left P1 element \\
\hline UM BUS 016 & Polygnathus glaber & right $\mathrm{P} 1$ element \\
\hline UM BUS 017 & Polygnathus glaber & left P1 element \\
\hline UM BUS 018 & Polygnathus glaber & left P1 element \\
\hline UM BUS 019 & Polygnathus glaber & left P1 element \\
\hline UM BUS 020 & Polygnathus glaber & left P1 element \\
\hline UM BUS 021 & Polygnathus glaber & right $\mathrm{P} 1$ element \\
\hline UM BUS 022 & Polygnathus glaber & left P1 element \\
\hline UM BUS 023 & Polygnathus glaber & left P1 element \\
\hline UM BUS 024 & Polygnathus glaber & left P1 element \\
\hline UM BUS 025 & Polygnathus glaber & left P1 element \\
\hline UM BUS 026 & Polygnathus glaber & left P1 element \\
\hline UM BUS 027 & Polygnathus glaber & right $\mathrm{P} 1$ element \\
\hline UM BUS 028 & Polygnathus glaber & right $\mathrm{P} 1$ element \\
\hline UM BUS 029 & Polygnathus glaber & right $\mathrm{P} 1$ element \\
\hline UM BUS 030 & Polygnathus glaber & right $\mathrm{P} 1$ element \\
\hline UM CTB 001 & Polygnathus communis & right $\mathrm{P} 1$ element \\
\hline UM CTB 002 & Polygnathus communis & right $\mathrm{P} 1$ element \\
\hline UM CTB 003 & Polygnathus communis & right $\mathrm{P} 1$ element \\
\hline UM CTB & Polygnathus communis & right $\mathrm{P} 1$ element \\
\hline & POl & \\
\hline
\end{tabular}

Inv. $\mathbf{N r}$

UM BUS 001

UM BUS 002

UM BUS 003

UM BUS 004

UM BUS 005

UM BUS 008

UM BUS 009

UM BUS 010

UM BUS 011

UM BUS 012

UM BUS 013

UM BUS 014

UM BUS 015

UM BUS 016

UM BUS 017

UM BUS 020

UM BUS 021

UM BUS 022

UM BUS 023

UM BUS 025

UM BUS 026

UM BUS 027

UM BUS 030

UM CTB 001

UM CTB 005
UM BUS 024

UM BUS 028

UM CTB 003

\section{Taxon}

Polygnathus glaber Polygnathus glaber Polygnathus glaber Polygnathus glaber Polyathus glaber Polygnathus glaber Polygnathus glaber Polygnathus glaber Polygnathus glaber Polygnathus glaber Polygnathus glaber Polygnathus glaber Polygnathus glaber ygnathus glaber Polygnathus glaber Polygnathus glaber Polygnathus glaber Polygnathus glaber Polygnathus glaber Polygnathus glaber Polygnathus glaber Polygnathus glaber Polygnathus glaber ygnathus glaber Pongthus glaber Polygnathus communis Polygnathus communis
UM CTB 006

UM CTB 007

UM CTB 008

UM CTB 009

UM CTB 010

UM CTB 011

UM CTB 012

UM CTB 013

UM CTB 014

UM CTB 015

UM CTB 016

UM CTB 017

UM CTB 018

UM CTB 019

UM CTB 020

UM CTB 021

UM CTB 022

UM CTB 023

UM CTB 024

UM CTB 025

UM CTB 026

UM CTB 027

UM CTB 028

UM CTB 029

UM CTB 030

UM CTB 031

UM CTB 032

UM CTB 033

UM CTB 034
Polygnathus communis Polygnathus communis Polygnathus communis Polygnathus communis Polygnathus communis Polygnathus communis Polygnathus communis Polygnathus communis Polygnathus communis Polygnathus communis Polygnathus communis Polygnathus communis Polygnathus communis Polygnathus communis Polygnathus communis Polygnathus communis Polygnathus communis Polygnathus communis Polygnathus communis Polygnathus communis Polygnathus communis Polygnathus communis Polygnathus communis Polygnathus communis Polygnathus communis Polygnathus communis Polygnathus communis Polygnathus communis Polygnathus communis left P1 element left P1 element left $\mathrm{P} 1$ element right P1 element left P1 element right P1 element right P1 element right P1 element right P1 element right P1 element left $\mathrm{P} 1$ element right P1 element right $\mathrm{P} 1$ element right $\mathrm{P} 1$ element right $\mathrm{P} 1$ element left P1 element left element left P1 element left P1 element left P1 element left P1 element left P1 element left P1 element left P1 element left P1 element left P1 element left P1 element left P1 element right $\mathrm{P} 1$ element
Table 1. 3D models of Polygnathus glaber and of Polygnathus communis. Collection: University of Montpellier, France.

\section{INTRODUCTION}

This contribution presents 3D models of 64 Famennien (Late Devonian) conodont elements belonging to two Polygnathus species (see Table 1 and Fig. 1). All elements correspond 
to platform (P1) elements, located at the rear of the conodont feeding apparatus. Polygnathus communis was sampled by 34 elements from two levels of the Col des Tribes section (CTB; Montagne Noire, France) (Girard et al. 2014) and Polygnathus glaber by 30 elements from one level of the Buschteich section (BUS; Saxo-Thuringia, Germany) (Girard et al. 2017). They illustrate the morphological variation between and within the species, including bilateral asymmetry and growth.

The 3D surface of these elements were used in a geometric morphometric analysis complementing an extensive 2D quantitative study (Renaud et al. 2021). Based on a set of sliding semi-landmarks located at the edge of the platform and on the carina, this study aimed at disentangling the different components of the morphological variation in Late Devonian Polygnathus P1 elements. The 3D morphometric analysis improved the description of the geometric changes involved in growth and bilateral asymmetry and provided evidence that the balance between the two components of shape variance varies across species. Allometry was most pronounced in Polygnathus communis, leading from small, heart-shaped to large, lanceolate platforms. In contrast, bilateral asymmetry was most pronounced in Po. glaber, suggestive in this species of a strict directional asymmetry. On the mean shape of left elements, the posterior margin extended more ventrally, the posterior platform was more elevated and displayed a shallower groove, as confirmed by the example of actual elements (Fig. 1). The reverse is true for the right element, with, however, less offset between the ventral extension of the posterior and anterior margins. Knowing that the left blade is assumed to insert behind the right one, based on existing clusters (Donoghue and Purnell 1999; Martínez-Pérez et al. 2016), the geometric differences between right and left elements, evidenced on the 3D models, could be associated with the asymmetrical pairing of the elements during occlusion.

\section{METHODS}

Digitization of the specimens was performed using an X-ray microtomograph $(\mu \mathrm{CT})$ Phoenix nanotomeS on the AniRA-Immos platform of the SFR Biosciences (UMS 3444, ENS Lyon) at a cubic voxel resolution of $1 \mu \mathrm{m}$. The scanning parameters were as follow: $100 \mathrm{kV}, 70 \mu \mathrm{A}, 3000$ projections at $360^{\circ}$ with no filter. The 3D surfaces were extracted semi-automatically within AVIZO 9 (Thermofisher Scientific) using the segmentation threshold selection tool. The 3D surfaces are provided in .ply format, and can therefore be opened with a wide range of freeware.

\section{ACKNOWLEDGEMENTS}

We acknowledge the contribution of SFR Biosciences (UMS3444/ CNRS, US8/Inserm, ENS de Lyon, UCBL) AniRa-ImmOs facility. We particularly thank Mathilde Bouchet for her kind assistance during the scanning sessions. The research was supported by the ANR ECODEV (ANR-13-BSV7-005) and the Project Marcon (Labex CeMEB). This is contribution ISEM 2020-226.

\section{BIBLIOGRAPHY}

Donoghue, P. C., Purnell, M. A. 1999. Mammal-like occlusion in conodonts. Paleobiology 25(1), 58-74.

Girard, C., Cornée, J.-J., Charruault, A.-L., Corradini, C., Weyer, D., Bartzsch, K., Joachimski, M. M., Feist, R. 2017. Conodont biostratigraphy and palaeoenvironmental trends during the Famennian (Late Devonian) in the Thuringian Buschteich section (Germany). Newsletters on Stratigraphy 50(1), 71-89. https://doi.org/10.1127/nos/2016/0318

Girard, C., Cornée, J.-J., Corradini, C., Fravalo, A., Feist, R. 2014. Palaeoenvironmental changes at Col des Tribes (Montagne Noire, France), a reference section for the Famennian of north Gondwana-related areas. Geological Magazine 151, 864-884. https://doi.org/10.1017/S0016756813000927

Martínez-Pérez, C., Rayfield, E. J., Botella, H., Donoghue, P. C. 2016. Translating taxonomy into the evolution of conodont feeding ecology. Geology 44, 247-250. https://doi.org/10.11 30/G37547.1

Renaud, S., Ecalle, B., Claisse, P., Charruault, A.-L., Ledevin, R., Girard, C. 2021. Patterns of bilateral asymmetry and allometry in Late Devonian Polygnathus conodonts. Palaeontology. https://doi.org/10.1111/pala.12513 
A. Po. glaber
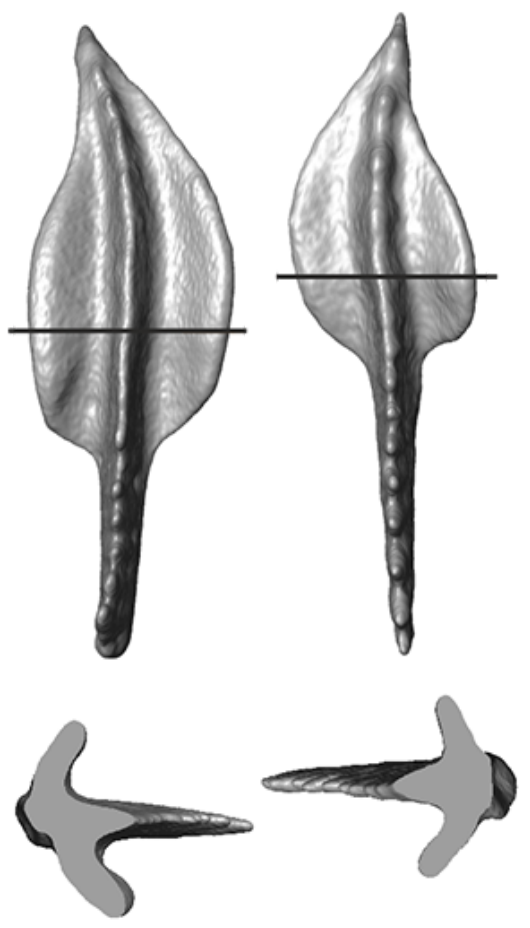

B. Po. communis

(large)
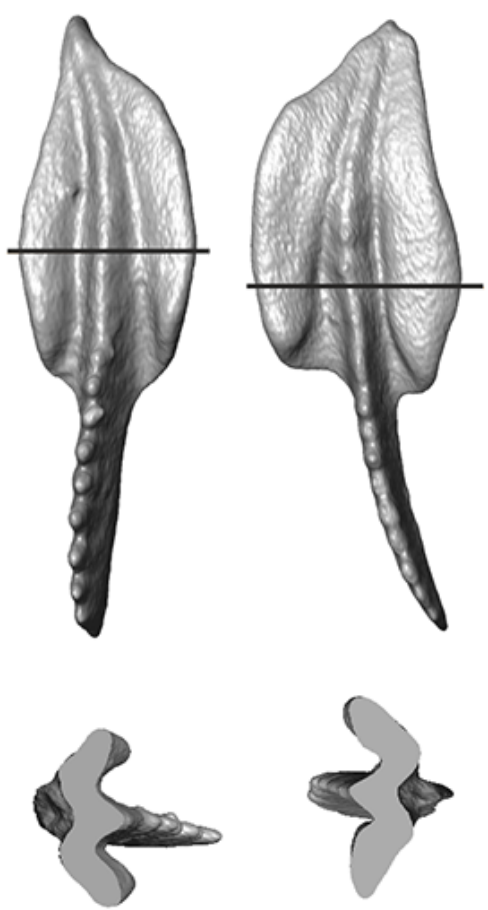

C. Po. communis (small)
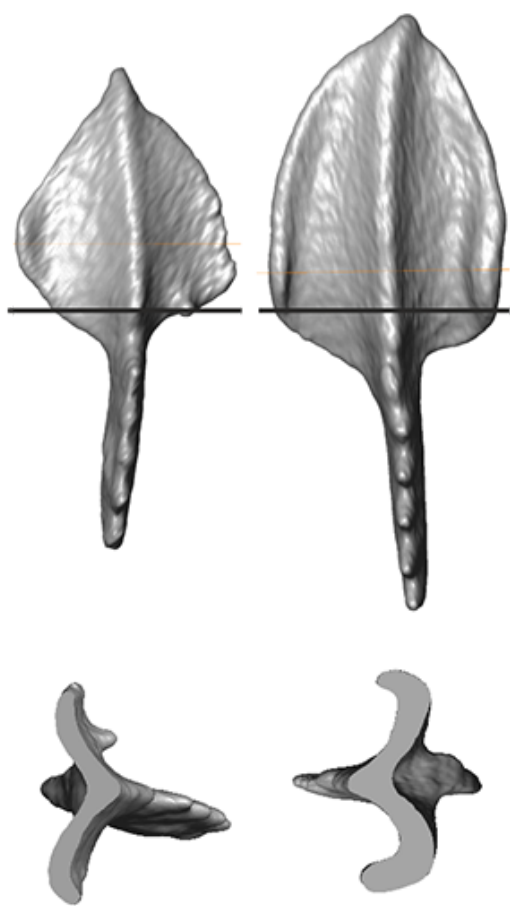

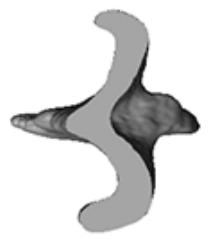

Figure 1. Illustrations based on isolated right and left elements of Po. glaber (A), large Po. communis (B) and small Po. communis (C). (A, B, C) left element to the left and right element to the right. Top panels, oral view; bottom panels, profile view. The position of the slice corresponding to the profile view is marked by a line on the oral view. Elements not to scale. Specimens figured: (A) Po. glaber right (UM BUS 027) and left (UM BUS 026); (B) large Po. communis left (UM CTB 010) and right (UM CTB 009); (C) small Po. communis left (UM CTB 006) and right (UM CTB 003). 